\title{
Pembangunan Masyarakat Berbasis Pengembangan Ekonomi Pesantren
}

\author{
Fitria Nurul Azizah ${ }^{1)}$, Musyafa Ali ${ }^{2)}$ \\ ${ }^{1}$ Pascasarjana IAIN Purwokerto \\ ${ }^{2}$ Fakultas Ilmu Tarbiyah dan Keguruan, UIN Sunan Kalijaga \\ *Email korespondensi: fitria.fathima@gmail.com
}

\begin{abstract}
This research focuses on the three main functions of boarding schools by revealing how Pondok Pesantren Rubat Mbalong Ell Firdaus conducts economic activities in pesantren and community development, and how islamic economic analysis related to community development based on economic development. This research is a type of field research through a qualitative descriptive approach. Data collection techniques use observation, interviews, and documentation. The results of the study illustrate that Pondok Pesantren Rubat Mbalong Ell Firdaus is a boarding school that implements economic activities and participates in community development by applying the educational format of tafaqquh and tadayyun. The concept of islamic education that is equipped with religious understanding while practising religious values, creating and applying the concept of Islam in view of the world. For the philosophical foundation of development in the Islamic perspective applied in Pondok Pesantren Rubat Mbalong Ell Firdaus namely tauheed uluhiyah, tauheed rububbiyah, khilafah, tazkiyyah an-nas and al-falah (optimizing human resources, applying god spot management, taking good care of nature, applying the Islamic mindset of rahmatallil religion and islam easy religion).
\end{abstract}

Keywords : Community Development, Islamic Economy

Saran sitasi: Azizah, F. N., \& Ali, M. (2020). Pembangunan Masyarakat Berbasis Pengembangan Ekonomi Pesantren. Jurnal Ilmiah Ekonomi Islam, 6(03), 645-653. doi: http://dx.doi.org/10.29040/jiei.v6i3.1410

DOI: http://dx.doi.org/10.29040/jiei.v6i3.1410

\section{PENDAHULUAN}

Tiga pilar utama pembangunan nasional, yaitu, (1) terpenuhinya seluruh kebutuhan jasmaniah, sandang, pangan dan sebagaianya; (2), terpenuhinya kebutuhan batiniah, pendidikan, kesehatan dan lain sebagainya. (3), terpenuhinya kesejahteraan hidup. Tujuan utama pembangunan nasional yakni terciptanya masyarakat yang makmur dan sejahtera. Dari pengertian diatas maka bidang ekonomi menjadi salah satu sektor penting dalam proses pembanguna masyarakat (Chakim, 2004).

Islam memposisikan manusia sebagai poros penggerak proses pembangunan dalam kehidupan. Ibn Khaldun menyatakan bahwa Islam tidak membedabedakan manusia, Islam melihat pada pengakuan dan kepatuhan pada Tuhan-Nya. Islam menyebutkan pokok pondasi pembangunan yaitu: tauheed uluhiyah, tauheed rububbiyah, khilafah, tazkiyyah an-nas dan al-falah. Sumber prinsip tersebut yakni Al-qur'an dan Sunnah (Mudrajad Kuncoro, 2010) . Dalam proses pembangunan lembaga masyarakat sanagt dibutuhkan kontribusinya. Setiap lembaga harus mau mengambil peran dalam proses pembangunan masyarakat terutama masyarakat yang berada di lingkungan pedesaan. Satu dari sekian bnayk lembaga yang berada di masyarakat pedesaan dan memiliki andil yang cukup strategis yakni pesantren (Syariah et al., 2014).

Untuk menaggapi perubahan sosial dalam masyarakat, pesantren harus meiliki perspektif, orientasi, dan harapan dimasa kini dan kedepan. Dengan begiru pesantren harus kembali pada tiga fungsi utamanya.(1), pusat pengkaderan ulama. (2), pencetak SDM yang handal. (3), lembaga pemberdayaan masyarakat. Dari penjelsan tersebut pondok pesantren menjadi lini yang berperan mentransformasikan proses sosial, dan tidak hanya mengedepankan aspek keagamaan saja. Namun demikian, masih banyak pesantren yang hanya menitikberatkan pada satu titik saja, dengan mempertahankan "pendirian semula" yakni sebagai lembaga pengkader ulama dan belum mampu 


\section{Jurnal Ilmiah Ekonomi Islam, 6(03), 2020, 646}

mengembangkan funsinya sebagai lembaga pencetak sumber daya manusia yang handal dan sebagai lembaga pemberdayaan masyarakat (NS, 2010).

Dalam penelitian dilkukan oleh Mirza Maulana yang menunjukan bahwa pondok pesantren memberdayakan masyarakat melalui tiga kegiatan yakni keagamaan, pendidikan, dan keterampilan dan pemberdayaan (Al-Kautsari, 2014). Dalam penelitian Abdul Basit juga di sebutkan bahwa pemberdayaan ekonomi di pesantren lebih ditujukan bagi santri sebagai bekal untuk menjalani kehidun setelah kel;uar dari pondok (Basit, 2009). Hasil dari penelitian yang dilakukan oleh Aulia Nur Inayah menunjukan bahwa pemberdayaan ekonomi santri yang dilakukan melalui budaya profetik, dengan meniru suri tauladan Nabi Muhammad SAW dalam menjalankan kegiatan ekonomi. Dari berbagai jenis penelitian yang sebelumnya pernah dilakukan dapat diambil kesimpulan bahwa bebrapa pondok pesantren telah melakukan kegiatan ekonomi dengan fariasi yang berbeda-beda, namun dari sekian banyak penelitian terdahulu belum ada penelitian yang membahas tentang kegiatan perekonomian berbasis pesantren dalam upaya pembangunan masyarakat.

Berdasarkan hasil penelitian dilakukan oleh peneliti, perbedaan penelitian ini terletk pada objek penelitian, lokasi, dan fokus penelitian. Peneliti memilih salah satu pondok pesantren yang berada di Cilacap, yakni Pondok Pesantren Rubat Mbalong Ell Firdaus. Adapun alasan pemilihan lokasi ini dikarenakan Pondok Pesantren Rubat Mbalong Ell Firdaus memiliki usaha dibidang ekonomi pesantren yang berfariatif, adapun bidang ekonomi yang dikembangkan yakni pertanian dan hortikultura, perikanan, peternakan, bangunan, kepontren, keterampilan tangan, laundry syariah, dan koperasi baruci mart. Tidak hanya itu Pondok Pesantren Rubat Mbalong Ell Firdaus menerapkan kegiatan pembangunan masyarakat melalui kegiatan mitra dengan berbagai UMKM, menjadi pelopor berdirinya berbagai komunitas di bidang ekonomi, bakti sosial, penanaman pohon, focus group discussion, dan sosialisasi.

Selain membangun masyarakat disekitar pondok pesantren, Pondok Pesantren Rubat Mbalong Ell Firdaus juga ikut barpartisipasi dalam berbagai kegiatan yang diselenggarakan oleh berbagai instansi dalam upaya pembangunan masyarakat diantaranya adalah mengikuti berbagai kegiatan seminar nasional di berbagai instansi, mengikuti berbagai even dan keikutsertaan dalam lomba Inovasi Teknologi Tepat Guna. selain itu Pondok Pesantren Rubat Mbalong Ell Firdaus pernah meraih juara 2 (dua) Lomba Inovasi Teknologi Tepat Guna kategori masyarakat dan mahasiswa dengan inovasi berjudul "Pupuk Organik Cair Mbalong Kulit Pisang Sebagai Solusi Pemanfaatan Limbah Kulit Pisang dari Industri Rumahan Sale Pisang”. Selain itu, Pengasuh Pondok Pesantren Rubat Mbalong Ell Firdaus juga mewakili Propinsi Jawa tengah sebagai narasumber dalam acara seminar model pemberdayaan pesantren pada Festival Ekonomi Syariah (FESyar) di Bandung pada tahun 2017 dan juga menjadi perwakilan Regional Jawa sekaligus sebagai narasumber dalam kegiatan ISEF di Surabaya ditahun yang sama. Selain menjadi narasumber dalam kegiatan tersebut, pengasuh juga sering diundang untuk menjadi narasumber dalam berbagai kegiatan seminar terkait dengan pemberdayaan ekonomi pesantren. Pondok Pesantren Rubat Mbalong Ell Firdaus juga mendapatkan apresiasi dari Gubernur Jawa Tengah, Ganjar Pranowo pada saat melakukan kunjungan ke Pondok Pesantren Rubat Mbalong Ell Firdaus.

Jenis penelitian yang penyusun gunakan dalam penelitian ini adalah penelitian lapangan (Field Research) yang bersifat deskriptif kualitatif (Arikunto, 2013). Penyusun melakukan studi kasus di Pondok Pesantren Rubat Mbalong Ell Firdaus, Tambaksari, Kedungreja, Cilacap. Penitian dilakukan secara langsung terkit pengembangan ekonomi yang ada di Pondok Pesantren Rubat Mbalong Ell Firdaus, Tambaksari, Kedungreja, Cilacap. Data dikumpulkan melalui observasi secara langsung, wawancara dan dokumentasi. Observasi dilakukan dalam rangka mengamati kegiatan subjek dan objek di lapangan. Metode wawancara ini penyusun gunakan untuk menggali informasi atau data tentang hal-hal yang berhubungan dengan pembangunan masyarakat berbasis pengembangan ekonomi Pesantren Rubat Mbalong Ell Firdaus. Setelah data terkumpul kemudian peneliti melakukan analisis data dengan cara mereduksi, menyajikan dan memverifikasi (Sugiyono, 2010). Setelah data di analisis peneliti juga menganalisis atau menuji keabsahan data dengan teknik triangulasi (Sugiyono, 2009).

Terealisasinya penelitian ini ditujukan untuk dapat digunakan sebagai bahan acuan dalam pembangunan masyarakat berbasis ekonomi, khusunya pada lembaga pondok pesantren dan juga masyarakat pada umumnya. Sebagai refrensi bagi 
lembaga pondok pesantren lain dalam upaya pengembangan dan pembanguna masyarakat berbasis ekonomi. Selain itu hasil penelitian ini juga dapat digunakan sebagai model, masukan ataupun solusi bagi lembaga lain yang ingin mengembangkan kegiatan pembangunan masyarakat berbasis kegiatan ekonomi.

\section{METODE PENELITIAN}

Jenis penelitian yang penyusun gunakan dalam penelitian ini adalah penelitian lapangan (Field Research) yang bersifat deskriptif kualitatif, yaitu suatu penelitian yang dimaksudkan untuk mengumpulkan informasi mengenai suatu variabel, keadaan atau gejala menurut apa adanya pada saat penelitian dilakukan (Arikunto, 2013). Penyusun melakukan studi kasus di Pondok Pesantren Rubat Mbalong Ell Firdaus, Tambaksari, Kedungreja, Cilacap. Penitian dilakukan secara langsung dan cermat bagaimana pengembangan ekonomi yang ada di Pondok Pesantren Rubat Mbalong Ell Firdaus, Tambaksari, Kedungreja, Cilacap.

Objek penelitian dalam penelitian ini adalah pembangunan masyarakat berbasis pengembangan ekonomi Pesantren Rubat Mbalong Ell Firdaus Tambaksari Kedungreja, Cilacap. Teknik pengumpulan data dalam suatu penelitian merupakan langkah yang paling utama, karena bertujuan untuk mendapatkan data (Sugiyono, 2009). Untuk mendapatkan data-data yang dibutuhkan dan relevan dengan penelitian, ada beberapa metode pengumpulan data yang digunakan dalam penelitian ini, yaitu:

a. Metode Observasi

Observasi sebagai teknik pengumpulan data mempunyai ciri spesifik bila dibandingkan dengan teknik yang lain, yaitu wawancara dan kuesioner. Jika wawancara dan kuesioner selalu berkomunikasi dengan orang, maka observasi tidak terbatas pada orang, tetapi juga objek-objek alam yang lain.

Taknik pengumpulan data dengan observasi digunaan bila, penelitian berkenaan dengan perilaku manusia, proses kerja, gejala-gejala alam dan bila responden yang diamati tidak terlalu besar (Sugiyono, 2010).

Penyusun melakukan observasi untuk mendapatkan data kegiatan dan aktifitas perkembangan Pondok Pesantren Rubat Mbalong Ell Firdaus dari aspek pendidikan, sosial, budaya, dan ekonomi. Serta bagaimana pembangunan masyarakat sekitar yang masuk dalam bagian objek penelitian ini. b. Metode Wawancara

Wawancara adalah percakapan dengan maksud tertentu. Percakapan dilakukan oleh dua pihak, yaitu pewawancara (interviewer) yang mengajukan pertanyaan dan terwawancara (interviewer) yang memberikan jawaban atas pertanyaan tersebut (Herdiansyah, 2014).

Metode wawancara ini penyusun gunakan untuk menggali informasi atau data tentang hal-hal yang berhubungan dengan pembangunan masyarakat berbasis pengembangan ekonomi Pesantren Rubat Mbalong Ell Firdaus. Dimana penyusun mewawancarai Pengasuh Pondok Pesantren Rubat Mbalong Ell Firdaus yaitu KH. Muhammad Achmad Hasan Mas'ud, Pengurus Pondok Pesantren Rubat Mbalong Ell Firdaus yaitu Priyadi Abdul Ghofur, dan Udin Zulkarnaen, Pengelola Unit Usaha Pengembangan Ekonomi Pondok Pesantren Rubat Mbalong Ell Firdaus. Santri Pondok Pesantren Rubat Mbalong Ell Firdaus yaitu Elok Zamzani Masfufah, dan Mitra usaha Pondok Pesantren Rubat Mbalong Ell Firdaus yaitu Ibnu Mas'ud.

Adapun metode dokumentasi yang diperlukan penyusun sebagai pelengkap hasil penelitian adalah:

1) Gambaran umum Pondok Pesantren Rubat Mbalong Ell Firdaus yang meliputi sejarah berdirinya pondok, letak geografis pondok, visi,misi, dan misi pondok, struktur organisasi pondok, dan bentuk pembangunan masyarakat yang dilakukan oleh pondok.

2) Mendokumentasikan pada saat dilakukan wawancara, kondisi pondok, kondisi unit pengembangan ekonomi, dan dokumentasi kegiatan pembangunan masyarakat.

3) Data tentang profil BARUCI Mart, profil Kepontren ELBAS, dan profil PANCIMAS.

\section{HASIL DAN PEMBAHASAN}

\subsection{Hasil penelitian}

Pondok Pesantren Rubat Mbalong Ell Firdaus merupakan lembaga yang berbentuk yayasan. Nama yayasan Pondok Pesantren Rubat Mbalong Ell Firdaus adalah Yayasan Rubat Tarim Al Barokah. Yayasan ini berdiri pada tahun 2009 di desa Tambaksari Rt 01/Rw 04 Kecamatan Kedungreja, Kabupaten Cilacap. Ketua Pembina yayasan adalah KH Muhamad Achmad Hasan Mas'ud.

Pondok Pesantren Rubat Mbalong Ell Firdaus menerapkan pengamalan agama sekaligus penerapan kreativitas yaitu dengan mengerjakan konsep 


\section{Jurnal Ilmiah Ekonomi Islam, 6(03), 2020, 648}

managemen yang baik. Seperti kalimat yang terdapat pada logo pondok yaitu jaufuhu al 'ilmu wal 'amal. Pondok Pesantren Rubat Mbalong Ell Firdaus merupakan lembaga pendidikan agama islam yang berorientasi kepada Pesantren berbasis Pertanian, Peternakan, Perikanan, dan Life Skill menuju kepada Pondok Pesantren Ekonomi Mandiri.

Adapun kegiatan ekonomi pesantren yang diterapkan di Pondok Pesantren Rubat Mbalong Ell Firdaus meliputi:

\begin{tabular}{|c|c|c|}
\hline No & $\begin{array}{c}\text { Nama } \\
\text { Kegiatan } \\
\text { Ekonomi }\end{array}$ & Kegiatan Usaha \\
\hline & \multirow{8}{*}{$\begin{array}{l}\text { Pertanian dan } \\
\text { Hortikultura }\end{array}$} & Jamur tiram \\
\hline & & Pembibitan apotik/warung hidup \\
\hline & & Pembibitan kayu tahunan \\
\hline & & Produksi pupuk padat dan cair \\
\hline & & $\begin{array}{l}\text { Pembibitan tanaman keras } \\
\text { (jati, mahoni, akasia, dan kakao) }\end{array}$ \\
\hline & & Palawija dan persawahan \\
\hline & & Penyemaian sayur mayor \\
\hline & & Pepaya california \\
\hline \multirow{4}{*}{2} & \multirow{4}{*}{ Perikanan } & $\begin{array}{l}\text { Pengelolaan ternak ikan } \\
\text { gurameh }\end{array}$ \\
\hline & & Pengelolaan ternak ikan jaer \\
\hline & & Pengelolaan ternak lele, patin \\
\hline & & Budidaya azzola micropyla \\
\hline \multirow{7}{*}{3} & \multirow{7}{*}{ Peternakan } & $\begin{array}{l}\text { Peternakan unggas mentok dan } \\
\text { bebek }\end{array}$ \\
\hline & & Peternakan unggas soang \\
\hline & & Peternakan kelinci \\
\hline & & Peternakan marmot \\
\hline & & Peternakan kambing garut \\
\hline & & Peternakan sapi \\
\hline & & Cacing Lumbricus \\
\hline 4 & $\begin{array}{l}\text { Usaha Bahan } \\
\text { Bangunan }\end{array}$ & Produksi batakko dan paving \\
\hline \multirow{2}{*}{5} & \multirow{2}{*}{ Kepontren } & Tepung Mocaf \\
\hline & & Ayam Sari \\
\hline \multirow[t]{2}{*}{6} & \multirow{2}{*}{$\begin{array}{l}\text { Keterampilan } \\
\text { Tangan }\end{array}$} & $\begin{array}{l}\text { Produksi sandal Kenthir dan } \\
\text { Jeger }\end{array}$ \\
\hline & & Batik \\
\hline 7 & $\begin{array}{l}\text { Laundry } \\
\text { Syariah }\end{array}$ & Usaha laundry syariah \\
\hline 8 & $\begin{array}{l}\text { Koperasi } \\
\text { Baruci Mart }\end{array}$ & $\begin{array}{l}\text { Penjualan barang-barang } \\
\text { UMKM dan hasil kerajinan } \\
\text { santri } \\
\text { (kerja sama dengan masyarakat) }\end{array}$ \\
\hline
\end{tabular}

Dalam menjalankan kegiatan ekonomi pesantren, Pondok Pesantren Rubat Mbalong Ell Firdaus bermitra dengan beberapa pihak, yaitu instansi pemerintah, universitas, pelaku usaha, pesantren lain, dan juga melalui jaringan alumni pesantren. Instansi pemerintah yang bermitra dengan Pondok Pesantren Rubat Mbalong Ell Firdaus adalah Bank Indonesia, Dinas Pertanian dan BP2KP Cilacap, Ditjen Holtikultura Departemen Pertanian Jakarta Selatan. Untuk usaha yang bermitra dengan pelaku usaha adalah kerajinan sandal dengan pengusaha sandal Cibaduyut, PT Puskomedia Indonesia Kreatif, dan Komunitas PANCIMAS. Selain itu pengasuh Pondok Pesantren Rubat Mbalong El Firdaus menjadi dewan pengawas di koperasi BARUCI Mart (Koperasi Bambu Runcing Cilacap).

\subsection{Pembahasan}

\section{Analisis Kegiatan Pembangunan Masyarakat Berbasis Pengembangan Ekonomi Pesantren Rubat Mbalong Ell Firdaus.}

Upaya kyai dalam memberdayakan santri dan masyarakat sekitar untuk memberdyakan ekonomi dalam rangka membangun masyarakat disekitar pondok pesantren akhir-akhir ini mulai berkembang. Potensi-potensi yang ada dilingkungan pondok dan masyarakat kini menjadi bidang garapan dalam upaya mengembangkan ekonomi berbasis pesantren dengan model pemberdayaan masyarakat. Direktorat Departemen Agama RI menyebutkan ada empat jenis pesantren dalam usaha pengembangan ekonomi yakni: agribisnis, agrobisnis, pedagangan, dan jasa.

Pada posisi dimana terjadi sinergitas antara pesantren dan masyarakat dalam hal pengembangan ekonomi pesantren, mampu menghadirkan realitas baru bahwa pesantren dapat memosisikan sebagai partner sekaligus ikon perubahan untuk penguatan ekonomi masyarakat. Sejlan dengan halm ini pesantren juga akan menjadi mandiri dan fundamental yang kuat. Sudjatmoko meyatakan bahwa pembangunan perekonomian bukan hanya tentang ekonominya, tetapi juga pola pikir, kesadaran dan pandangan kedepan masyarakat (NS, 2010).

Pondok pesantren Rubat Mbalong Ell Firdaus menerapkan konsep tafaquh dan tadayyun sebagai format kegiatan pondok, dimana santri dilatih untuk mandiri dan aktif. Usaha yang dilakukan oleh pengasuh Pondok Pesantren Rubat Mbalong Ell Firdaus dalam mengembangkan kegiatan ekonomi santri yakni "Jaufuhu Al 'Ilmu Wal 'Amal”. Sehingga 


\section{Jurnal Ilmiah Ekonomi Islam, 6(03), 2020, 649}

bukan hanya ruhiah akan tetapi ketrampilan yang lain juga dikembangkan sebagai bekal bagi kehidupan santri setelah keluar dari pondok nantinya.

Adapun kegiatan pengembangan ekonomi di Pondok Pesantren Rubat Mbalong Ell Firdaus diantaranya:

a. Pertanian dan Hortikultura

Pertanian dan hortikutura yang terdiri dari pertanian padi, hortikultura (penyemaian sayurmayur, palawija, pembibitan tanaman keras, pembibitn kayu tahunan, pembibitan apotik/warung hidup, pepaya california, tanaman hias, dan buah-buahan), budidaya jamur tiram, produksi pupuk padat dan cair, cacing lumbricus dan budidaya azolla micropyla.

Pertanian dan holtikultura di Pondok Pesantren Rubat Mbalong Ell Firdaus mendapatkan bimbingan dari Laboratorium PHPT (Pengamatan Hama dan Penyakit Tanaman) Jatilawang, Banyumas, yaitu bapak Anas Anggoro Cahyo Edi, SP dan juga mendapatkan bantuan dari Bank Indonesia sebagai bagain dari program CSR (Coorporate Social Responsibility) dalam bentuk kawasan pangan lestari. Pengelolaan pertanian dan hortikultura yang dilakukan di Pesantren Rubat Mbalong Ell Firdaus menggunakan sistem organik.

Mutolih menyatakan bahwa tujuan utama dari kegiatan ini tidak lain adalah memberi bekal kepada santri saat nanti kembali ke masyarakat, selain itu santri juga diharapkan dapat mengembangkan, mengenalkan serta memberdayakan di lingkungan temapat tinggalnya.

b. Perikanan

1) Pembesaran Ikan

Perikanan yang diterapkan oleh pondok Rubat Mbalong Ell Firdaus masih dalam tahap pembesaran, dan rencana kedepan akan dikembangkan dalam tahap pemijahan. Dalam pengelolaan perikanan ini dilakukan secara gotong royong, dan masih mendapat bimbingan dari luar pondok pesantren, yaitu dari alumni pondok. Untuk pembesaran ikan sendiri menggunakan kolam biasa dan sistem biofok. Untuk biofok sendiri berjumlah 17 kolam, sedangkan yang biasa (kotak) terdapat 8 kolam. Untuk pakan ikan sendiri menggunakan pakan alternatif yaitu magot yang berasal dari ampas tahu dan gesek, selain itu diselingi dengan pakan azola.

2) Azzola micropyla

Azzola micropyla adalah tanaman yang berprotein tinggi yang diberikan pada hewan ternak seperti ayam, bebek, entog, dan lainlain sebagai makanan tambahan. Biasanya hewan ternak hanya diberikan makanan yang hanya mengandung karbohidrat saja, seperti dedek dan fur atau dedek dan nasi. Ketika makanan hewan ternak yang diberikan dicampur dengan azzola, maka terdapat kolaborasi antara karbohidrat dan protein. Untuk percampuran azzola sendiri yaitu $60: 40,60 \%$ dari dedek, nasi, dan fur, dan $40 \%$ dari azzola.

c. Peternakan

Untuk pelatihan peternakan sendiri didapatkan dari warga. Untuk peternakan mentok belajar dari Roil, Rejamulya, Peternakan sapi belajar dari peternak sapi yaitu Rahmat, Gandrungmangu, sedangkan untuk jenis hewan yang lain merupakan pengalaman santri sendiri yang telah menerapkan dirumahnya. Untuk jenis hewan yang diternakan di Pondok Pesantren Rubat Mbalong Ell Firdaus sendiri meliputi kambing, sapi, mentok, kelinci, puyuh, unggas dan cacing lumbricus.

d. Usaha Bahan Bangunan

Usaha bahan bangunan adalah usaha yang dilakukan oleh santri dalam mencukupi kebutuhan bahan bangunan pondok pesantren. Usaha bahan bangunan yang dikembangkan oleh Pondok Pesantren Rubat Mbalong Ell Firdaus adalah pembuatan paving dan batako. Untuk pemasaranya sendiri dilakukan secara kondisional, yaitu apabila ada yang memesan maka dibuatkan. Untuk produksi bahan bangunan sendiri diprioritaskan untuk konsumsi pondok dalam hal pembangunan pondok. Yaitu untuk membangun bangunan pondok pesantren, jalan dan juga kolam-kolam ikan untuk kegiatan ekonomi pesantren.

e. Koperasi Pondok Pesantren Kepontren ELBAS

Koperasi yang ada di Pondok Pesantren Rubat Mbalong Ell Firdaus merupakan koperasi yang dikembangkan oleh keluarga besar Pondok Pesantren Ell Firdaus. Koperasi ELBAS didirikan pada tanggal 25 April 2018. ELBAS adalah singkatan dari Ell Firdaus Bakti Umat 


\section{Jurnal Ilmiah Ekonomi Islam, 6(03), 2020, 650}

Sejahtera. Dalam menjalankan usahanya, Kepontren ELBAS dibantu oleh reka dari KSU/BMT El-Sejahtera.

Untuk usaha yang dikembangkan oleh Kepontren ELBAS saat ini baru ayam sari dan tepung mocaf. Akan tetapi untuk kedepanya akan dikembangakan penjualan hasil peternakan, perikanan dan pertanian yang dimiliki oleh Pondok Pesantren Rubat Mbalong Ell Firdaus.

f. Keterampilan tangan

1) Produksi sandal Kenthir dan Jeger

Usaha pembuatan sandal Kenthir dimulai pada Mei 2017 dimana para santri mendapatkan pelatihan membuat sandal dari produsen sandal di Cibaduyut. Alat-alat yang digunakan untuk pembuatan sandal ini berasal dari investor yang tergabung dalam komunitas PANCIMAS. Untuk pemasaranya sendiri menggunakan jaringan alumni sebagai reseller produk, selain itu juga di pasarkan di koperasi BARUCI Mart, melalui siswa-siswa yang bersekolah, dan juga melakukan pemasaran melalui berbagai even diantaranya bazar, festival ekonomi syariah, dll.

2) Kegiatan membatik

Kegiatan membatik di Pondok Pesantren Rubat Mbalong Ell Firdaus berupa kegiatan pelatihan membatik. Awal adanya kegiatan membatik adalah adanya pelatihan membatik dari Euis Rohaini, kemudian santri diajak untuk melihat kegiatan membatik di kerajinan batik Rajasamas Maos. Tujuannya pembekalan ketrampilan membatik bagi santri putri.

g. Laundry Syariah

Sistem pengelolaan yang dilakukan di Laundry Syariah sendiri dimulai dari pengumpulan baju hingga penataan. Untuk harga laundry perkilogram 4000 untuk pakaian biasa, sedangkan selimut berkisar 7000-1000 perkilogram tergantung ukuran selimutnya. Khusus untuk baju santri dibawa ke pondok lagi oleh Aziz. Untuk pemasaran laundry syariah menggunakan berbagai media diantaranya facebook, waatsapp, brosur, dan mount of mount. Target konsumen laundry syariah antara lain santri Ponpes Rubat Mbalong Ell Firdaus, Ponpes Ell Firdaus, masyarakat sekitar ponpes, siswa sekolah-sekolah, perangkat desa, polisi, bidan, guru, mushola, dan masyarakat lainya.

h. BARUCI Mart (Bambu Runcing Cilacap)

BARUCI Mart didirikan pada tanggal 29 Februari 2018, Minimarket BARUCI Mart sendiri terletak di Jl.Penatusan No 219 RT 03/RW 03 Desa Jatisari , Kec.Kedungreja , Kab.Cilacap. BARUCI Mart merupakan anak usaha dari koperasi BARUCI. Dalam mengelola BARUCI Mart pengelola melakukan study banding ke minimarket-minimarket terdekat. Diantaranya adalah minimarket 212 mart, Alfamart, dan lain-lain. Untuk operasional BARUCI Mart hampir sama seperti minimarket pada umumnya, akan tetapi bentuk hukum dari BARUCI Mart sendiri adalah koperasi serba usaha (KSU). Untuk saat ini anggota Koperasi BARUCI Mart sudah mencapai 400 anggota. Setiap anggota yang bergabung dengan BARUCI Mart membayar simpanan pokok sebesar Rp. 500.000,-. Dan juga simpanan wajib sebesar Rp.50.000,-.

Pemasaran yang dilakukan oleh BARUCI Mart menggunakan berbagai strategi pemasaran diantaranya menggunakan media sosial, dan juga mount of mount. Untuk rencana jangka panjang koperasi BARUCI Mart adalah dapat berdiri di setiap kecamatan di Cilacap.

\section{Analisa Ekonomi Islam Terkait Pembangunan Masyarakat Berbasis Pengembangan Ekonomi Pesantren Rubat Mbalong Ell Firdaus}

Terdapat lima pondasi filosofis pembangunan dalam perspektif Islam yaitu: tauheed uluhiyah, tauheed rububbiyah, khilafah, tazkiyyah an-nas dan al-falah. Prinsip utama pembangunan didasarkan pada dua sumber utama Islam yaitu Al-qur'an dan Sunnah. Kelima pondasi ini menjadi syarat minimum yang diperlukan dalam pembangunan, yaitu:

a. Tauheed Uluhiyah

Merupakan kepercayaan hamba hanya pada Kemahatunggalan zat penguasa alam. Dalam konteks pembangunan diartikan sebagai sumber daya yang bermanfaat untuk orang banyak, dan bukan hanya untuk kepentingan pribadi atau sekelompok golongan tertentu karena sumber daya alam adalah milikNya.

Wujud tauheed uluhiyah yang diterapkan oleh Pondok Pesantren Rubat Mbalong Ell Firdaus adalah memanfaatkan sumber daya 


\section{Jurnal Ilmiah Ekonomi Islam, 6(03), 2020, 651}

pondok pesantren untuk kemaslahatan santri dan masyarakat untuk mencapai kemandirian ekonomi.

KH. Muhamad Achmad Hasan Mas'ud, Pengasuh Pondok Pesantren Rubat Mbalong Ell Firdaus mengatakan bahwa santri dilatih untuk mengikuti kegiatan-kegiatan ekonomi yang di laksanakan di pondok. Kegiatan ekonomi yang dilaksanakan di pondok tersebut mendapat bimbingan dari profesional. Pihak yang berkontribusi berasal dari instansi pemerintah, instansi swasta, dan juga mitra pondok pesantren. Santri yang telah selesai belajar di pondok, akan menjadi santri yang mandiri dan dapat memberdayakan masyarakat dilingkungan tempat tinggalnya. Kegiatan ekonomi di Pondok Pesantren Rubat Mbalong Ell Firdaus selain didukung oleh pihak-pihak yang berkontribusi dalam hal pengetahuan, biaya, ataupun teknologi, juga didukung juga oleh ketersediaan sumber daya alam yang ada di pondok dalam melakukan kegiatan ekonomi. Faktor tersebut sangat mendukung bagi kesuksesan pondok untuk memberdayakan santri dan juga masyarakat sekitar Pondok Pesantren Rubat Mbalong Ell Firdaus.

\section{b. Tauheed Rububiyyah}

Merupakan kepercayaan seorang hamba yang percaya bahwa Tuhanlah sang maha penentu hidup dan penuntun kesuksesan hamba yang percaya akan kuasaNya. Dalam konteks pembangunan diartikan Tuhan ikut berkontribusi dalam kesuksesan seorang hamba, dan bukan semata-mata atas usaha sendiri (Mudrajad Kuncoro, 2010).

Pengasuh telah memberikan fondasi bagi santrinya yaitu dengan ajaran ketauhidan yang kuat. Dimana sikap-sikap tawaqal, keikhlasan dalam bekerja, dan kedisiplinan dicontohkan dan diterapkan dengan baik oleh pengasuh. Pengasuh menerapkan konsep managemen god spot yaitu manajemen titik Tuhan dalam diri manusia yaitu dengan menjadikan Tuhan sebagai tujuan hidup. Hal ini diterapkan dengan managemen sens dan the power of dzikr. La maksuda illallah, La matluba Illallah, La himmaka illallah. yaitu dengan menerapkan managemen pendidikan, managemen publik, dan managemen organisasinya. Managemen god spot tersebut diterapkan dalam aktifitas ekonomi di Pondok Pesantren Rubat Mbalong Ell Firdaus.

c. Khilafah

Merupakan cerminan dari diri manusia sebagai khalifah fil ard, dimana menempatkan manusia sebagai wakil atas sumber daya alam semesta yang diamanahkan kepadanya dan juga keimanan manusia yang menjadi contoh atau teladan yang baik bagi manusia lainya (Mudrajad Kuncoro, 2010).

Konsep khilafah yang ditanamkan di Pondok Pesantren Rubat Mbalong Ell Firdaus mengacu pada tanggungjwab manusia untuk mengelola alam raya. Dalam hal ini Pondok Pesantren Rubat Mbalong Ell Firdaus memberikan pengetahuan dan keterampilan bagaimana mengelola sumber daya alam dengan baik dan dapat memberdayakan alam, sehingga bisa bermanfaat bagi banyak orang. Misalnya dengan teknologi pemanfatan limbah atau kotoran sapi untuk menjadi bio gas dan pupuk organik. Sistem organik yang diterapkan oleh Pondok Pesantren Rubat Mbalong Ell Firdaus melatih santri untuk memahami bahwa alam disediakan oleh tuhan untuk dirawat dengan baik. Dan dapat menerapkan sistem organik yang dipelajari di pondok pesantren dan dapat memperkenalkan pada masyarakat luas.

d. Tazkiyyah an-nas

Di alam semesta ini, manusia berkedudukan sebagai agen perubahan dan agen pembangunan. Oleh karena itu perubahan dan pembangunan bertujuan untuk kebaikan-kebaikan orang lain, dan bukan hanya bagi kepentingan diri sendiri (Mudrajad Kuncoro, 2010).

Konsep pengembangan ekonomi yang dilakukan di Pondok Pesantren Rubat Mbalong Ell Firdaus ditujukan untuk kepentingan banyak orang. Dan ditanamkan konsep bagaimana cara menggarap dunia yang baik agar nantinya Islam dapat menjadi agama yang rahmatallil alamin baik dalam hal dunia maupun akhirat. Sebagai bentuk pembangunan masyarakat, Pondok Pesantren Rubat Mbalong Ell Firdaus menjadi penjembatan antara investor, donatur, dan juga pengusaha untuk dapat memberdayakan santri dan masyarakat sekitar pondok.

Harapan dari pengasuh dengan adanya kegiatan pembangunan masyarakat yang diterapkan di Pondok Pesantren Rubat Mbalong 


\section{Jurnal Ilmiah Ekonomi Islam, 6(03), 2020, 652}

Ell Firdaus dapat mengurangi kenakalan ramaja dan dapat memberdayakan remaja agar memiliki skill berwirausaha.

Pondok Pesantren telah membuat link pasar, kemitraan untuk menguatkan ekonomi masyarakat dan juga memberikan sumber daya yang dimiliki oleh Pondok Pesantren Rubat Mbalong Ell Firdaus untuk kemaslahatan masyarakat sekitar pondok.

Pengasuh melakukan pendekatan dengan masyarakat dengan ikut aktif dalam kegiatan masyarakat dan memberikan sumbangsih kepada masyarakat baik berupa materi ataupun non materi. Setiap 3 atau 4 bulan melakukan pembagian bibit tanaman pada masyarakat dan melakukan roan ke masyarakat setiap satu minggu sekali. Selain itu, pondok pesantren juga mengadakan kegiatan siraman rohani kepada masyarakat baik urusan agama ataupun urusan dunia yang profit oriented.

e. Alfalah

Merupakan konsep keberhasilan manusia, dimana keberhasilanya didunia mempengaruhi keberhasilan di akhirat, keberhasilanya didunia tidak menyimpang dari petunjuk dan bimbingan Alloh SWT yang telah ditetapkan. Oleh karena itu, keberhasilan seseorang didunia selaras dengan persiapanya bagi kehidupan di akhirat (Mudrajad Kuncoro, 2010).

Pondok Pesantren Rubat Mbalong Ell Firdaus menerapkan format pendidikan tafaqquh dan tadayyun yaitu memahami agama sekaligus mengamalkan nilai-nilai agama, berkreasi dan menerapkan konsep Islam dalam mamandang dunia.

Penerapan kegiatan ekonomi sebagai syiar agama menempatkan Islam sebagai agama yang rahmatal il 'alamin. Santri dan masyarakat dapat memadang Islam sebagai agama yang memberikan kesejahteraan didunia dan akhirat. Masyarakat diharapkan memikiri pemikiran terbuka terhadap dunia luar terutama dalam hal ekonomi. Sehingga santri dan masyarakat memandang Islam sebagai agama yang mudah, yang tidak hanya mengatur urusan akhirat saja tetapi juga urusan dunia. Dengan pola pikir demikian santri masyarakat dapat meraih falah atau kebahagiaan dunia dan akhirat.
Terdapat dampak positif dan negatif dalam kegiatan pengembangan ekonomi Pesantren Rubat Mbalong Ell Firdaus.

Dampak positif yang ditimbulkan dengan adanya kegiatan pengembangan ekonomi pesantren adalah sebagai berikut:

1) Mengurangi kenakalan remaja dan pergaulan bebas

2) Menambah wawasan dan pengalaman santri dalam hal ekonomi

3) Meningkatkan kemandirian santri dan mempersiapkan santri utuk berwirausaha

4) Melatih tanggungjawab santri

5) Dapat membuka jaringan pemasaran produk UMKM.

6) Kepercayaan konsumen terhadap produk UMKM yang dipasarkan semakin tinggi.

7) Perhatian pemerintah terhadap UMKM semakin baik

\section{KESIMPULAN}

Berdasarkan hasil penelitian yang penyusun lakukan mengenai Pembangunan Masyarakat Berbasis Pengembangan Ekonomi Pesantren Rubat Mbalong Ell Firdaus, Tambaksari, Kedungreja Cilacap, maka dapat disimpulkan: Analisis Pelaksanaan Pembangunan Masyarakat Berbasis Pengembangan Ekonomi Pesantren Rubat Mbalong Ell Firdaus Tambaksari Kedungreja Cilacap Pondok Pesantren Rubat Mbalong Ell Firdaus merupakan Pondok Pesantren yang menerapkan kegiatan ekonomi. Adapun bentuk kegiatan pengembangan ekonomi pesantren yang dilakukan di Pondok Pesantren Rubat Mbalong Ell Firdaus meliputi pertanian dan hortikultura, perikanan, peternakan, usaha bahan bangunan, Kepontren ELBAS, keterampilan tangan, laundry Syariah, dan Koperasi BARUCI Mart. Selain melakukan kegiatan ekonomi pesantren, Pondok Pesantren Rubat Mbalong Ell Firdaus juga melakukan kegiatan pembangunan masyarakat dengan bermitra dengan berbagai UMKM, menjadi pelopor berdirinya berbagai komunitas di bidang ekonomi, bakti sosial, penanaman pohon, focus group discussion, dan sosialisasi.

\section{UCAPAN TERIMA KASIH}

Puji syukur kehadirat Allah SWT, Sholawat serta salam semoga tetap tercurahkan kepada junjungan kita nabi agung Muhammad SAW. Pada kesempatan kali 
Jurnal Ilmiah Ekonomi Islam, 6(03), 2020, 653

ini peneliti mengucapkan banyak terimakasih kepada ayah dan ibu yang telah mendukung saya, sehingga dapat terselesaikannya artikel ini. Tak lupa penulis juga mengucapkan terimakasih yang sebesar-besarnya kepada keluarga Pondok Pesantren Rubat Mbalong Ell Firdaus Kedungreja, santriwan santriwati, warga sekitar pondok yang telah membantu saya dalam melakukan penelitian dan juga teman-teman semua yang telah membverikan dorongan dan semangat kepada saya. Semoga Allah SWT membalas segala kebaikan kalian semua.

\section{REFERENSI}

Al-Kautsari, M. M. (2014). Pemberdayaan Masyarakat Berbasis Pondok Pesantren: Studi Pondok Pesantren ASWAJA Lintang Songo Desa Situmulyo Piyungan, Bantul. UIN Sunan Kalijaga.

Arikunto, S. (2013). Manajemen Penelitian. Rineka Cipta.

Basit, A. (2009). Program Pemberdayaan Ekonomi Pada Pondok Pesantren As-Salafiyah Desa Cicantayan Cisaat Sukabumi. UIN Syarif Hidayatulloh.
Chakim, S. (2004). Dakwah Pembangunan (Sebuah Model Pemberdayaan Masyarakat Pedesaan). Jurnal Studi Islam Dan Budaya, 2(1), 43-54. http://download.portalgaruda.org/article.php?arti cle $=47162 \& v a l=3909 \&$ title=Dakwah

Pembangunan (Sebuah Model Pemberdayaan Masyarakat Pedesaan)

Herdiansyah, H. (2014). Metodologi Penelitian Kualitatif (3rd ed.). Salemba Humanika.

Mudrajad Kuncoro. (2010). Ekonomika Pembangunan: Masalah, Kebijakan, dan Politik. Erlangga.

NS, C. F. Y. dan S. (2010). Model Pengembangan Ekonomi Pesantren. Stainpress.

Sugiyono. (2009). Metode Penelitian Kuantitatif Kualitatif dan $R \& D$. Alfabeta.

Sugiyono. (2010). Metode Penelitian Pendidikan Pendekatan Kuantitatif, Kualitatif, dan R\&D. Alfabeta.

Syariah, M. J., Islam, E., Pekalongan, S., No, K., \& Email, P. I. (2014). Potensi Pesantren. Hukum Islam, 12, 117-134. 